\title{
Roof Failure Mechanism and Control Technology of Large Section Open-Off Cut in Soft Rock Strata with Thin Thickness
}

\author{
Chen Li $\mathbb{D}^{1}{ }^{1}$ Jun Li, ${ }^{1}$ Xiaoyong Lian, ${ }^{1}$ Yongen $\mathrm{Li}^{2}{ }^{2}$ Qi Xue, ${ }^{3}$ and Jicheng Feng $\mathbb{D}^{4}$ \\ ${ }^{1}$ School of Energy \& Mining Engineering, China University of Mining and Technology (Beijing), Beijing 100083, China \\ ${ }^{2}$ China Energy Guoyuan Electric Power Group, Beijing 100033, China \\ ${ }^{3}$ Shanxi Gaohe Energy Co. Ltd, Changzhi 046000, China \\ ${ }^{4}$ School of Safety Engineering, North China Institute of Science and Technology, Langfang 065201, China \\ Correspondence should be addressed to Chen Li; leesin0225@163.com and Jicheng Feng; 13120008810@163.com
}

Received 6 January 2021; Accepted 6 May 2021; Published 17 May 2021

Academic Editor: Xiaowei Deng

Copyright $\odot 2021$ Chen Li et al. This is an open access article distributed under the Creative Commons Attribution License, which permits unrestricted use, distribution, and reproduction in any medium, provided the original work is properly cited.

\begin{abstract}
The open-off cut is used for equipment installation of working face before underground mining, and its sectional size is larger than that of the mining roadway. Therefore, the stability of open-off cut surrounding rock determines whether the panel can be put into operation. To solve the roof instability of open-off cut in the Wanli No.1 coal mine, the roof failure mechanism of open-off cut under weak composite rock strata with thin thickness was studied by field monitoring, theoretical analysis, and numerical simulation. First, the characteristics of surrounding rock and the basic law of strata behaviors were obtained by detailed field monitoring. Afterward, FLAC ${ }^{3 \mathrm{D}}$ numerical simulation and mechanical analysis were used to obtain the main mechanical control parameters of surrounding rock instability, and the existence of a soft interlayer above the roof is the main cause of roof instability. Based on this, the supporting parameters of the open-off cut were optimized and adjusted. The optimized parameters were applied to the adjacent 31207 open-off cut. The engineering practice showed that the optimized supporting parameters have an ideal control effect on roof stability.
\end{abstract}

\section{Introduction}

China currently relies on underground mining for $90 \%$ of its coal production [1]. Open-off cut is a special roadway where mining equipment is installed before underground coal mining [2]. The superlarge output of comprehensive mechanized coal mining working face determines the largescale coal mining equipment. Therefore, the section size of the cutting hole is larger than that of the ordinary mining roadway [3]. At the same time, the rock mass of coal seam is mostly in the low-strength sedimentary strata, and the surrounding rock mass is generally composed of multiple rock mass composite structures, which poses a certain threat to the safety of roadway engineering [4-7]. The stability of surrounding rock around the open-off cut directly determines whether the working face can be successfully put into operation [8].

Many scholars have performed a lot of research on roadway engineering under different conditions. In terms of soft rock roadway research, Du et al. $[9,10]$ studied the deformation characteristics of the soft roof in inclined coal seam by numerical analysis and put forward the support optimization scheme. Shen et al. [11, 12] studied the roadway failure rule and its mechanism under the condition of large deviation between vertical and horizontal stress of the coal seam. Li et al. [13,14] obtained the failure modes of deep roadway through field monitoring and proposed specific control schemes through numerical analysis, which provided references for engineering governance under similar geological conditions. The research results of large section roadway engineering are described [15-17]. Based on the practical problems in underground mining of coal mine, Hu et al. [3, 18] studied the supporting technology of large-span open-off cut. Gao et al. $[19,20]$ studied the deformation and failure mechanism of the surrounding rock of the ultralarge tunnel through the large-scale geomechanical model testing system, and they analyzed the evolution rules of displacement and stress 
under different support conditions. Aiming at the problem of large roof deformation of soft rock roadway with large section, Yan et al. [21] proposed the control system of the twice-formed roadway and "multi-support structure." In terms of composite roof research, Li et al. [22, 23] have studied the triggering effect of interlayer on surrounding rock failure. Jia et al. [24, 25] studied and analyzed that the main cause of roof caving accidents was the deterioration of roof rock assemblage. Ma et al. [26, 27] obtained the mechanics' mechanism of roadway instability caused by composite roofs through theoretical mechanics derivation. Chen et al. [28-30] obtained the mechanical properties and failure characteristics of composite samples, which have reference significance for the understanding of the failure of the composite roof.

To meet the output of the working face, large equipment must be used in the Wanli No.1 coal mine, so that the section of open-off cut is larger. In the previous engineering of openoff cut, the support parameters were obtained mainly by engineering analogy. Due to the good stability of surrounding rock in the previous project, the support parameters have not been changed. As a result, the supporting parameters of the 31206 open-off cut cannot meet the stability of its surrounding rock. Therefore, based on the problems meeting in the field, this study focuses on the failure mechanism of the weak composite roof through numerical simulation and theoretical analysis and puts forward the scientific support technology pertinently. It can guide similar engineering problems.

\section{Engineering Project}

2.1. Geological Survey. Wanli No.1 coal mine is located in the north of Dongsheng Coalfield in Ordos city, Inner Mongolia Autonomous Region of China. It is an oversize coal mine with an annual output of more than $6 \mathrm{Mt}$. The coal seam in Dongsheng coalfield has typical characteristics of shallow and thin bedrock. The roof of coal seam is weak in lithology, and the strata are complex.

The thickness of the coal seam in panel 31207 and panel 31206 was between 3.4 and $3.8 \mathrm{~m}$, averaging $3.6 \mathrm{~m}$. The structure of the coal seam was complex, and the roof was developed with mudstone gangue, as shown in Figure 1. The immediate roof of coal seam was sandy mudstone and medium sandstone, with an average thickness of $3.4 \mathrm{~m}$ and $1.4 \mathrm{~m}$, respectively, and the roof sandy mudstone contained gangue with an average thickness of $0.4 \mathrm{~m}$. The immediate floor of coal seam was fine sandstone and sandy mudstone, with an average thickness of $2.2 \mathrm{~m}$ and $3.6 \mathrm{~m}$, respectively.

2.2. Project Profile. The working face length of panel 31207 was $300 \mathrm{~m}$, and the design width and height of the open-off cut were $7.6 \mathrm{~m}$ and $3.6 \mathrm{~m}$, respectively. The section size of the 31206 open-off cut is the same as that of the adjacent 31207 open-off cut. 31206 open-off cut partial roof falling occurred before the open-off cut was officially put into use, so large density anchor cable reinforcement and even shed support had been carried out, as shown in Figure 2.
The supporting parameters of coal seam open-off cut are shown in Figure 3. The roof is supported by the method of "left-rotation non-longitudinal reinforcement rebar bolt + anchor cable $+W$ steel belt + metal welding net." The roof supported 9 bolts per meter, whose diameter and length were, respectively, $18 \mathrm{~mm}$ and $2500 \mathrm{~mm}$. The bolt spacing and row spacing were, respectively, $900 \mathrm{~mm}$ and $1000 \mathrm{~mm}$. Five roof anchor cables with a diameter of $17.8 \mathrm{~mm}$ were arranged on the roof, and they were $2 \mathrm{~m}$ between two rows. The two sides of the rib were, respectively, rod bolt with a diameter of $16 \mathrm{~mm}$ and FRP bolt with a diameter of $22 \mathrm{~mm}$, with a row spacing of $1000 \mathrm{~m}$.

\section{Field Monitoring and Results}

According to the previous engineering experience, the deformation of open-off cut was less than $50 \mathrm{~mm}$ during excavation. However, the deformation of the 31206 open-off cut was significantly larger, and the roof caving occurred at $243 \mathrm{~m}$ and $276 \mathrm{~m}$ away from pillar 31205 . After the occurrence of roof caving, the deep-base monitoring data near the roof caving were timely sorted out, and the mining pressure observation was strengthened in the abnormal area, mainly including the borehole imagine, cable pull-out test, and borehole core mechanics test. The schematic diagram of the fieldwork is shown in Figure 4.

3.1. Roof Deformation Monitoring. To monitor the mining pressure in time, a set of deep base point separation monitor was installed every $60 \mathrm{~m}$ in open-off cut during drivage. One measuring point was also installed at the intersection of roadway and open-off cut, and a total of 8 measuring points were arranged, as shown in Figure 4. The separation monitor was installed $5 \mathrm{~m}$ behind the heading face. The internal basis points of surrounding rock were $2 \mathrm{~m}, 4 \mathrm{~m}$, and $8 \mathrm{~m}$, respectively, as shown in Figure 5. Representative displacement data of monitoring points were selected and sorted out as shown in Figure 6.

The roof sag tended to increase as it got closer to panel 31207, and the roof deformation at the intersection of openoff cut and roadway was the largest, as is shown in Figure 6. Previous engineering experience shows that the roof would sag within $50 \mathrm{~mm}$ after open-off cut excavation, and the deformation of roadway was mainly within 7 days after excavation, and it tended to be stable after 15 days. However, there was no slowing trend of roadway roof displacement from the measuring point 3 to point 8 , and the roof displacement had reached $76 \mathrm{~mm}$ when the observation point 3 was observed on the 35th day. Meanwhile, observation points 7 and 8 have been observed for 20 days, and roof sag has reached $108 \mathrm{~mm}$ and $139 \mathrm{~mm}$, respectively. Roof deformation and failure were mainly concentrated in the shallow part within $2 \mathrm{~m}$ above the roof, and roof subsidence was larger than that of previous similar projects. Therefore, to prevent further dangerous accidents after two roof caving, one row of cable was forced to be strengthened between the two rows of cable. 


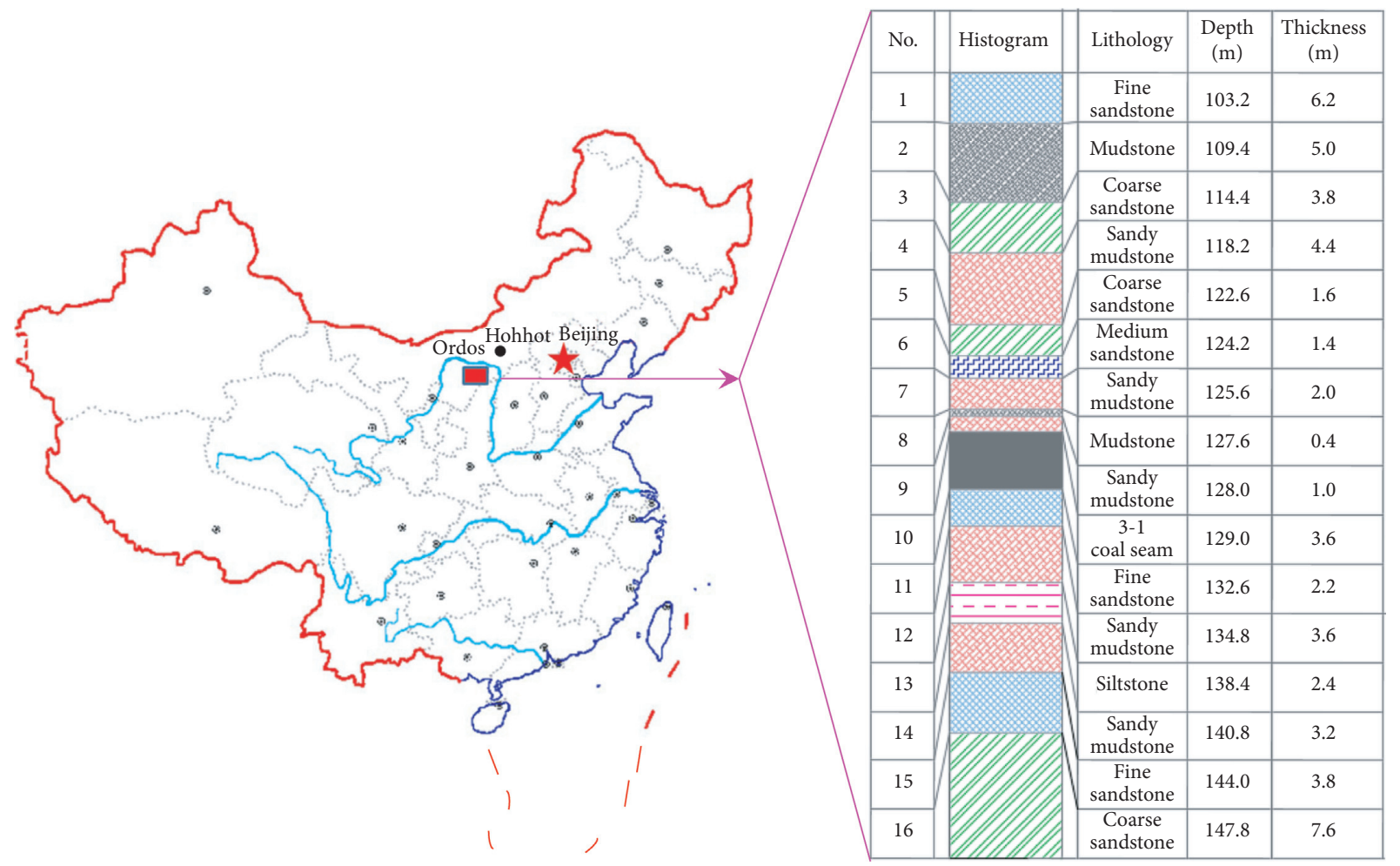

FIgUre 1: The location of the Wanli No.1 coal mine and the geological column of 31206 open-off cut.

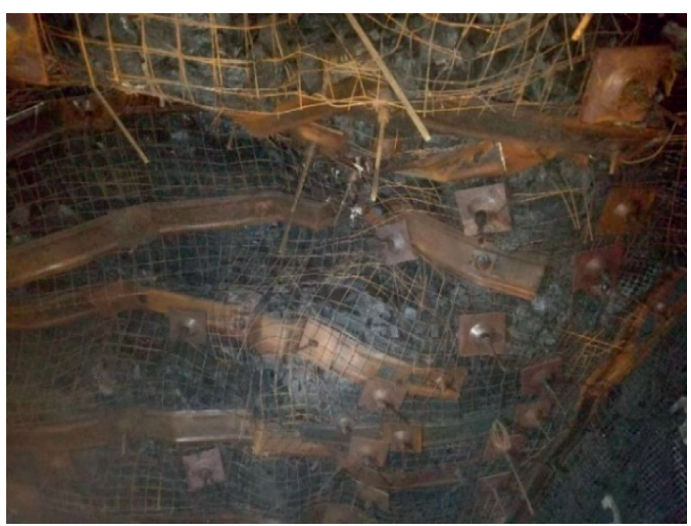

(a)

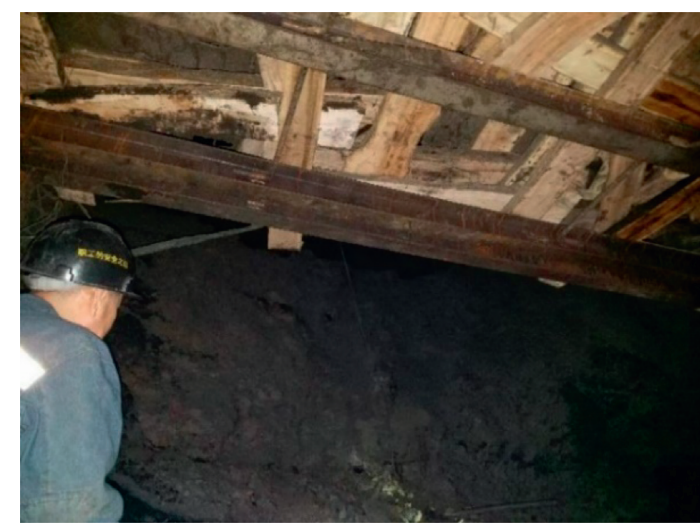

(b)

Figure 2: Photos of a seriously damaged roof. (a) Anchor cable reinforcement. (b) Shed support.

3.2. Roof Structure Detection. Borehole imaging detection was carried out at $243 \mathrm{~m}$ and $276 \mathrm{~m}$ where local roof falling occurred. The type TYGD10 rock drilling detector was used. The roof drilling was $28 \mathrm{~mm}$ in diameter and $8 \mathrm{~m}$ in depth. The location of measuring point is shown in Figure 4 . The results of borehole imaging are given in Table 1, and the rock drilling detector and representative failure images of the surrounding rock are shown in Figure 7.

The following conclusions can be drawn from the results of borehole imaging. The failure depth of open-off cut was mainly concentrated within $2.5 \mathrm{~m}$ above the roof, especially the shallow surrounding rock within $1.5 \mathrm{~m}$ of the roof, which contained many broken areas and obvious damage. Therefore, there was almost no carrying capacity within
$1.5 \mathrm{~m}$ above the roof, and there were interlayers between 2 and $3 \mathrm{~m}$ above the roof, most of which contained cracks. This interval had a certain residual carrying capacity. The rock layers with good integrity were distributed over $3 \mathrm{~m}$ above the roof. Besides, the lithologic distribution at different locations above the roof can be obtained by borehole imaging. The thickness of the interlayer at measuring points 1 and 2 was $0.40 \mathrm{~m}$ and $0.6 \mathrm{~m}$, respectively, and the distance from the roof was $1.6 \mathrm{~m}$ and $2.1 \mathrm{~m}$, respectively.

3.3. Cable Pull-Out Test. To obtain the actual anchoring effect of cable, the cable pull-out test in the abnormal roof area was carried out. Anchor cables with a diameter of $17.8 \mathrm{~mm}$ and a length of $6500 \mathrm{~mm}$ and $8000 \mathrm{~mm}$ were 


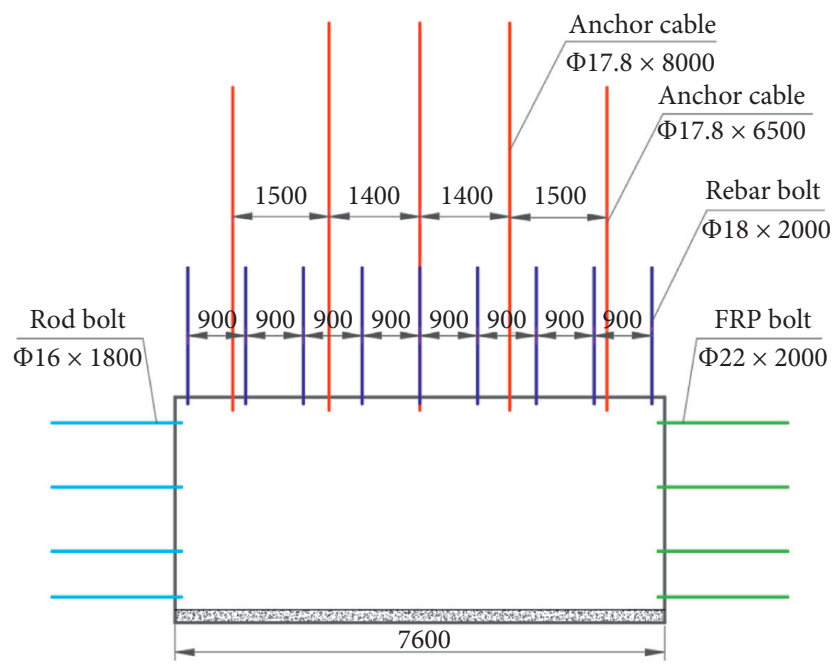

FIgURE 3: The supporting section of the open-off cut.

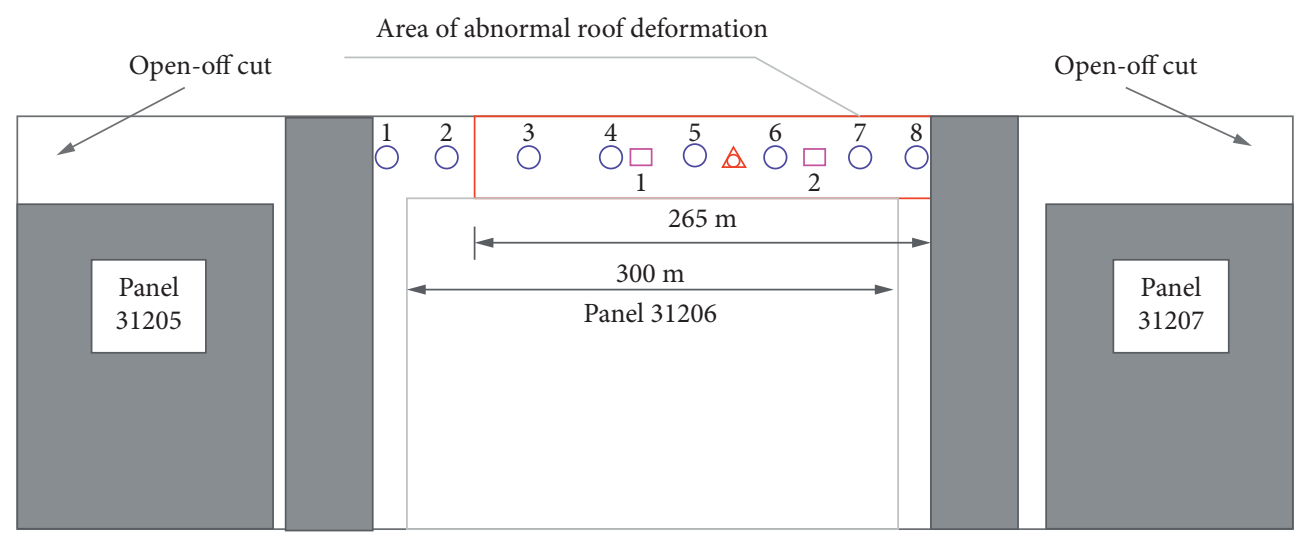

A Coring by drilling

Monitoring point of roof displacement

$\square$ Monitoring point of borehole imaging and cable drawing test

FIGURE 4: Schematic diagram of the deformation and monitoring position.

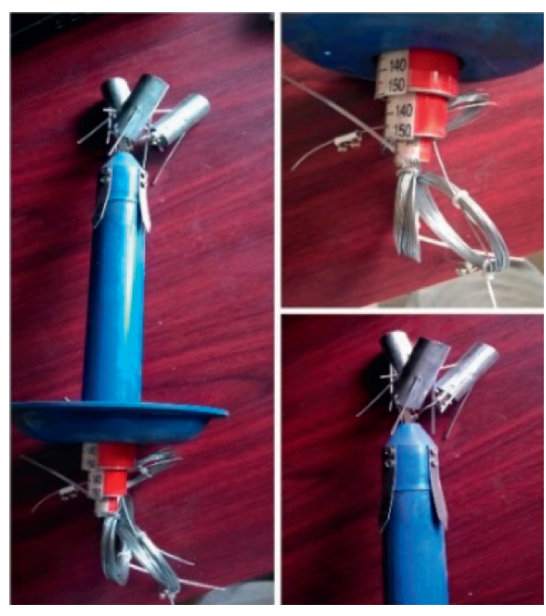

(a)

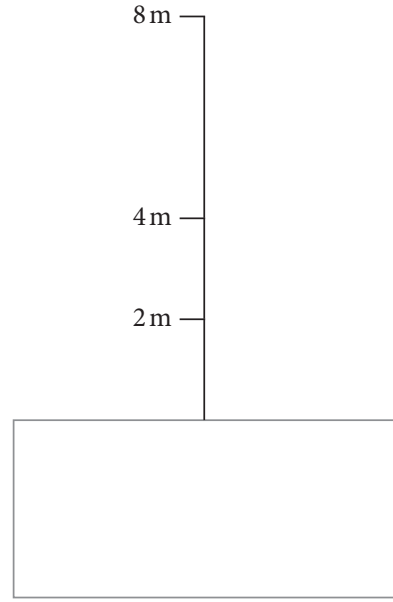

(b)

FIGURE 5: Separation monitor and its arrangement. (a) 3-basis points separation monitor. (b) Basic point arrangement of separation monitor. 


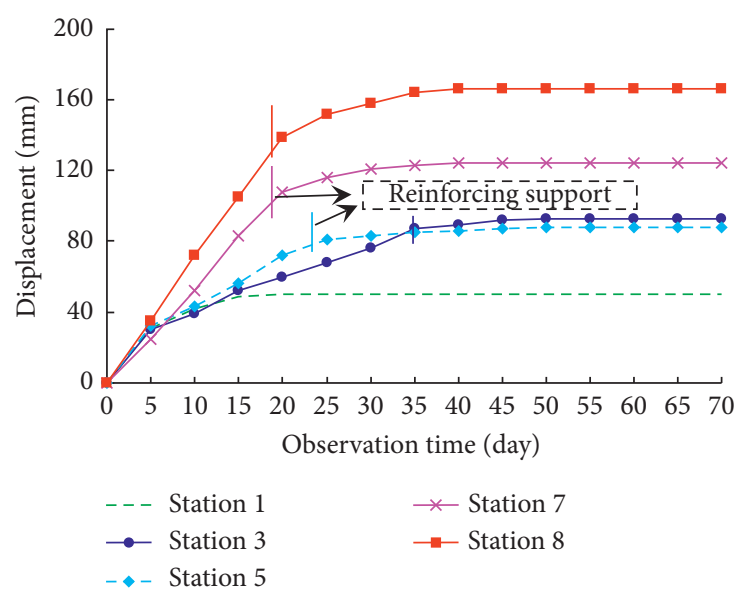

(a)

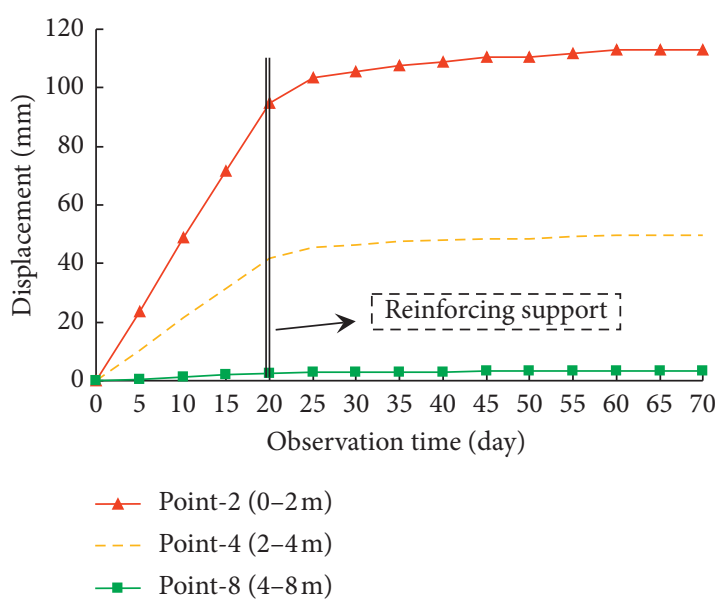

(b)

FIgURE 6: Characteristics of roof sag. (a) The final deformation of measuring points. (b) Roof displacement at measuring point 8.

TABLE 1: Borehole imaging results.

\begin{tabular}{lccccc}
\hline Monitoring point Number of broken areas & $\begin{array}{c}\text { Crushing length/ } \\
\text { number } \\
>20 \mathrm{~mm}>40 \mathrm{~mm}\end{array}$ & $\begin{array}{c}\text { Maximum crushing area length } \\
(\mathrm{mm})\end{array}$ & $\begin{array}{c}\text { Crushing depth (main/ } \\
\text { maximum) }\end{array}$ \\
\hline 1 & 12 & 5 & 3 & 72 & $<1.5 \mathrm{~m} / 1.96 \mathrm{~m}$ \\
2 & 9 & 4 & 1 & 66 & $<1.8 \mathrm{~m} / 2.37 \mathrm{~m}$ \\
\hline
\end{tabular}

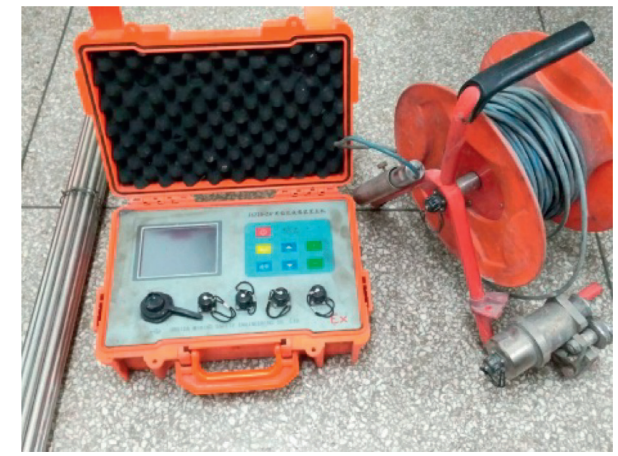

(a)

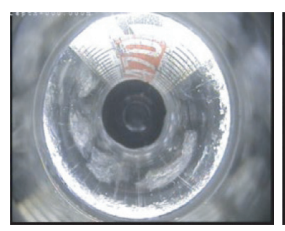

$1.29 \mathrm{~m}$

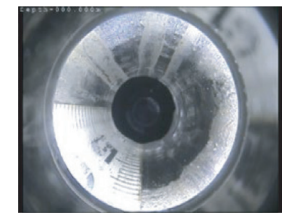

$0.39 \mathrm{~m}$

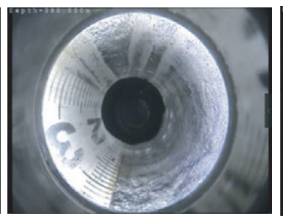

$1.69 \mathrm{~m}$

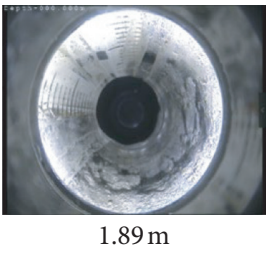

(b)
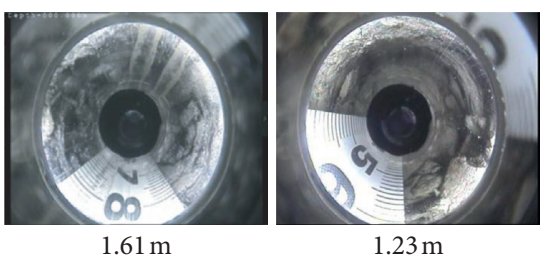

(c)

FIGURE 7: Borehole imaging instrument and detection results. (a) TYGD10 rock drilling detector. (b) Borehole image screenshot at point 1. (c) Borehole image screenshot at point 2.

selected. Two cables of each type, two $500 \mathrm{~mm}$ resin anchoring agents were used for each cable. The tail of the anchor cable was exposed to $200 \mathrm{~mm}$ after installation. Md18-250/53 cable tensioned pump was used for the cable pull-out test, and the location of the measuring point is shown in Figure 4. The results obtained when the cable was pulled out are given in Table 2.
As can be seen from Table 2, the anchoring force was greater when the length of the anchor cable was $6500 \mathrm{~mm}$. In addition, it can be seen from Figure 1 that the anchorage end of the $8000 \mathrm{~mm}$ anchor cable was partially located in the soft sandy mudstone, while the anchorage end of the $6500 \mathrm{~mm}$ cable was completely located in the medium and coarse sandstone rocks with high rock strength. According to the 
TABLE 2: Anchorage force test results.

\begin{tabular}{|c|c|c|c|c|}
\hline \multirow{2}{*}{ Anchor parameters $(\mathrm{mm})$} & \multirow{2}{*}{ Hole depth (mm) } & \multicolumn{3}{|c|}{ Anchorage force $(t)$} \\
\hline & & 1 & 2 & Average \\
\hline$\varphi 17.8 \times 8000$ & 7800 & 24.4 & 25.2 & 24.7 \\
\hline$\varphi 17.8 \times 6500$ & 6300 & 27.7 & 28.9 & 28.3 \\
\hline
\end{tabular}

cable drawing test, the anchorage position of the cable was closely related to the strength of the overlying rock, and the anchorage effect was better when the anchorage end was located in the hard rock.

3.4. Rock Mechanics Parameter Testing. To obtain the mechanical properties of roof rock, the open-off cut roof was drilled and cored. The borehole has a diameter of $50 \mathrm{~mm}$ and a depth of $8 \mathrm{~m}$. The testing process of core parameters is shown in Figure 8. According to the testing results of rock mechanics parameters and geological exploration drilling data, the rock mechanics parameters of 31206 open-off cut were obtained, as given in Table 3. As can be seen from Table 3, the surrounding rocks of the cut hole are all weak rocks. The compressive strength of the immediate roof sandy mudstone was only 16.9 MPa, and the sandy mudstone layer contained soft interlayers. Therefore, the self-bearing capacity of the roof is weak after the roadway excavation.

\section{Discussion}

When the stress of surrounding rock exceeds the strength of rock, it will be broken and plastic zone will be produced $[31,32]$. The surrounding rock in the plastic state may not produce large deformation immediately, but the macroscopic deformation and failure zone of surrounding rock must be within the plastic zone. Therefore, it is very important to study the morphology and size of plastic zone for understanding the failure mechanism of roadway.
The research method of numerical simulation and theoretical analysis plays an increasingly important role in geotechnical engineering [33-35]. Therefore, theoretical analysis and $\mathrm{FLAC}^{3 \mathrm{D}}$ numerical simulation were used to study the depth of plastic zone development in different roof rock assemblages and lithology. The length, width, and height of the numerical model were $50 \mathrm{~m}, 1.2 \mathrm{~m}$, and $50 \mathrm{~m}$, respectively, and the mesh size was $0.4 \mathrm{~m} \times 0.4 \mathrm{~m}$. The model fixed the boundary around and below, and the pressure coefficient was set at 1.4 based on the relevant geological data. The Mohr-Coulomb criterion was used to calculate the model, and initial stress equilibrium was performed by INI. The stratum division is changed according to different research contents, and the mechanical parameters of each stratum are given in Table 3.

\subsection{Influence of Lithologic on the Failure of Surrounding Rock}

4.1.1. Theoretical Analysis. At present, there is no theoretical formula for directly calculating the plastic zone of the surrounding rock of rectangular roadway. Based on the actual surrounding rock stress environment of the roadway and the theory of elasticity mechanics and the Mohr-Coulomb criterion, Ma et al. [36, 37] obtained the implicit equation for the plastic boundary $R_{0}$ of the surrounding rock of the circular roadway under the condition of bidirectional unequal pressure.

$$
\begin{aligned}
9(1-\lambda)^{2}\left(\frac{r}{R_{0}}\right)^{8} & +\left[-12(1-\lambda)^{2}+6(1-\lambda)^{2} \cos 2 \theta\right] \times\left(\frac{r}{R_{0}}\right)^{6}+\left[(1-\lambda)^{2}-\sin ^{2} \varphi\left(1+\lambda^{2}+\frac{2 C \cos \varphi}{P_{3} \sin \varphi}\right)^{2}\right] \\
& +\left[10(1-\lambda)^{2} \cos ^{2} 2 \theta-4(1-\lambda)^{2} \sin ^{2} \varphi \cos ^{2} 2 \theta-2(1-\lambda)^{2} \sin ^{2} 2 \theta-4\left(1-\lambda^{2}\right) \cos 2 \theta+(1+\lambda)^{2}\right]\left(\frac{r}{R_{0}}\right)^{4} \\
& +\left[-4(1-\lambda)^{2} \cos 4 \theta+2\left(1-\lambda^{2}\right) \cos 2 \theta-4\left(1-\lambda^{2}\right) \sin ^{2} 2 \varphi \cos 2 \theta-\frac{4 C(1-\lambda) \sin \varphi \cos 2 \theta}{P_{3}}\right]\left(\frac{r}{R_{0}}\right)^{2}=0
\end{aligned}
$$

where $C$ and $\varphi$ are the cohesion and internal friction angle of the surrounding rock, respectively; $R_{0}$ is the distance between the boundary of plastic zone and the center of the roadway, $\theta$ is the polar coordinate of any point, $r$ is the radius of the roadway, $P_{3}$ is the vertical stress, and $\lambda$ is the lateral pressure coefficient.

Before excavation, the stress environment at the fixed position of coal seam was given and constant, including vertical stress, horizontal stress, and lateral pressure coefficient. Therefore, according to equation (1), it can be concluded that when coal seam roadway was excavated, the roadway failure range around surrounding rocks was related to rock cohesion and friction angle. The relevant parameters (equivalent radius $4.18 \mathrm{~m}$, vertical stress $3.25 \mathrm{MPa}$, lateral pressure coefficient 1.4) of the open-off cut are taken into equation (1), and the radius of the surrounding rock plastic zone can be obtained by 


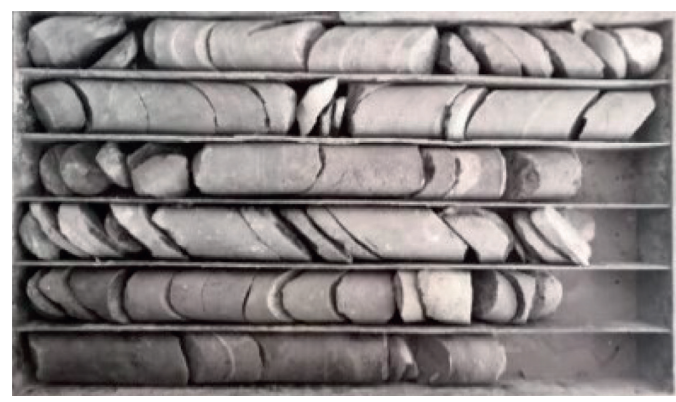

(a)

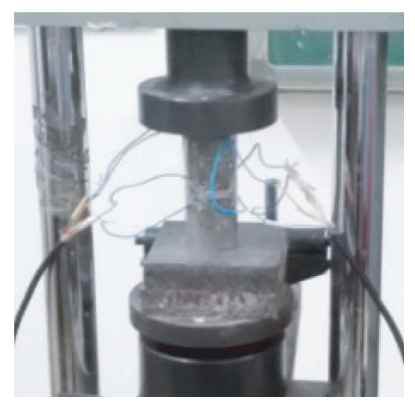

(b)

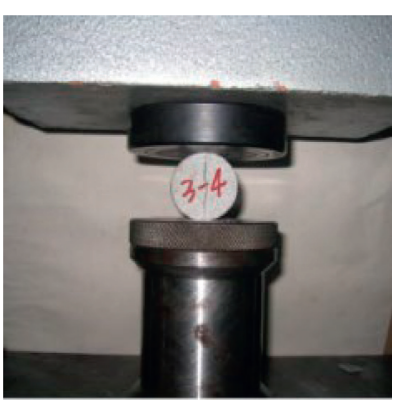

(c)

Figure 8: Rock mechanics parameter test. (a) Rock core sample. (b) Uniaxial compression test. (c) Splitting test.

TABLE 3: Rock mechanical parameter of open-off cut.

\begin{tabular}{lccccc}
\hline Lithology & $\begin{array}{c}\rho \\
\left(\mathrm{kg} \cdot \mathrm{m}^{-3}\right)\end{array}$ & $\begin{array}{c}\sigma_{\mathrm{c}} \\
(\mathrm{MPa})\end{array}$ & $\begin{array}{c}\sigma_{\mathrm{t}} \\
(\mathrm{MPa})\end{array}$ & $\begin{array}{c}\Phi \\
\left({ }^{\circ}\right)\end{array}$ & $\begin{array}{c}\mathrm{C} \\
(\mathrm{MPa})\end{array}$ \\
\hline $\begin{array}{l}\text { Fine sandstone } \\
\text { Mudstone }\end{array}$ & 2600 & 15.6 & 0.86 & 31 & 1.4 \\
Coarse & 2400 & 8.5 & 0.52 & 22 & 0.9 \\
$\begin{array}{l}\text { sandstone } \\
\text { Sandy mudstone }\end{array}$ & 2400 & 21.6 & 1.16 & 34 & 2.1 \\
Medium & 1500 & 16.9 & 0.69 & 29 & 1.1 \\
sandstone & 2200 & 31.2 & 1.12 & 32 & 2.5 \\
3-1 coal seam & 1500 & 12.1 & 0.81 & 27 & 1.2 \\
Siltstone & 2600 & 17.5 & 1.05 & 30 & 2.3 \\
Interlayer & 2100 & 3.5 & 0.15 & 20 & 0.2 \\
\hline
\end{tabular}

$\rho$, density; $\sigma_{\mathrm{c}}$, compressive strength; $\sigma_{\mathrm{t}}$, tensile strength; $\Phi$, internal friction angle; $\mathrm{C}$, cohesion.

changing the cohesion and internal friction angle, as shown in Figure 9. According to equation (1), the plastic zone of the roadway roof was negatively correlated with cohesion and internal friction angle, and the size of the plastic zone is directly determined by the soft rock stratum.

4.1.2. Numerical Analysis. The relationship between lithology and plastic zone was numerically simulated by the above numerical model. The rock stratum in the model was a single homogeneous sandy mudstone, and the rock mechanics parameters only took cohesion and internal friction angle as variables. The plastic zone distribution after cutting hole excavation was simulated when the cohesion was from $0.6 \mathrm{MPa}$ to $1.5 \mathrm{MPa}$, and the internal friction angle was from $20^{\circ}$ to $35^{\circ}$. The excavation of the model was consistent with the engineering practice. The width of the first excavation was $5.2 \mathrm{~m}$, and the width of the second excavation was $2.4 \mathrm{~m}$.

The numerical simulation results are shown in Figure 10. The range of plastic zone decreases with the increase of cohesion and internal friction angle. Besides, the plastic zone is more affected by cohesion.

\subsection{Influence of Weak Interlayer on the Failure of Surrounding Rock}

4.2.1. Theoretical Analysis. Liu et al. [27] simplified the roadway roof with a soft interlayer into a rectangular composite beam composed of three kinds of rocks as shown in Figure 11, and the intermediate rock layer was a soft stratum. Assume that the thickness of 3 strata above the roadway roof from the bottom to the top was $h 1, h 2$, and $h 3$, and the elastic modulus were $E 1, E 2$, and $E 3$, respectively. The rectangular composite beam with unit width was used for force analysis. For the convenience of calculation, it was assumed that the lithology and thickness of the upper and lower strata are equal, that is, $h 1=h 3, E 1=E 3$, and the bending moment on the cross-section was $M$. According to the mechanics of materials, the maximum tensile stress $\sigma h 1$ of the lower strata is shown in the following equation.

$$
\sigma_{h_{1}}=\frac{12 E_{1} M\left(h_{1}+0.5 h_{2}\right)}{E_{1}\left[\left(2 h_{1}+h_{2}\right)^{3}-h_{2}^{3}\right]+E_{2} h_{2}^{3}} .
$$

Since the bending moment $M$ of the composite beam only depended on constraint conditions and the load of the beam, it can be regarded as a fixed value. According to equation (2), when the thickness of the soft interlayer in the middle of the composite beam was fixed, the maximum tensile stress on the roof became smaller and smaller as the soft interlayer was further and further away from the roof. $\sigma h 1$ was directly related to $h 1 / h 2$, so the thickness variation of the soft interlayer was an important factor affecting the stability of the roof.

4.2.2. Numerical Analysis. Figure 12 is the numerical simulation results of the influence of different interlayer states on the plastic zone. The left side of each figure is the columnar diagram of the rock strata. According to Figure 12, we can get the shape and size of the plastic zone of the roadway roof when the thickness of the interlayer (red) is different or the position of the interlayer (red) is different.

When there was no influence of soft interlayer, the plastic zone depth of open-off cut roof was $1.6 \mathrm{~m}$, as shown in Figure 12(a). When the soft interlayer with the thickness of $0.4 \mathrm{~m}$ was located within the range of $2.0 \mathrm{~m}$ above the roof, the depth of plastic zone above the roof increased to $2.0 \mathrm{~m}$, and the plastic zone in the soft interlayer extended seriously, as shown in Figures 12(b)-12(d). When the soft interlayer with a thickness of $0.4 \mathrm{~m}$ was located at $2.4 \mathrm{~m}$ above the roof, the plastic zone depth of the roof was $2.8 \mathrm{~m}$. The soft interlayer has an obvious influence on the roof when it was located in a certain range above the roof, as shown in 


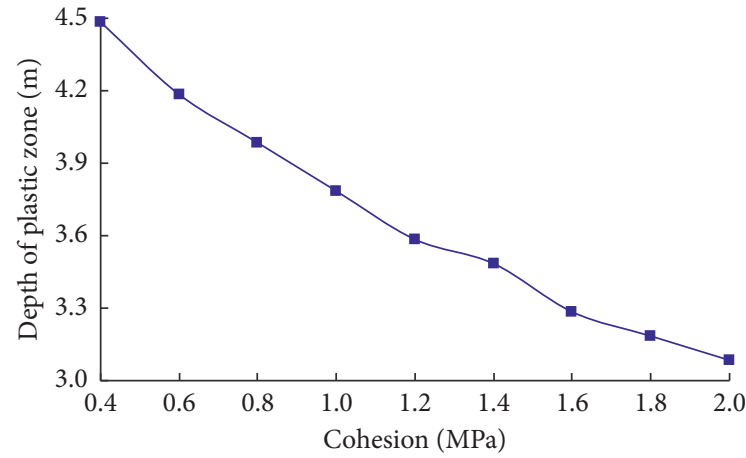

(a)

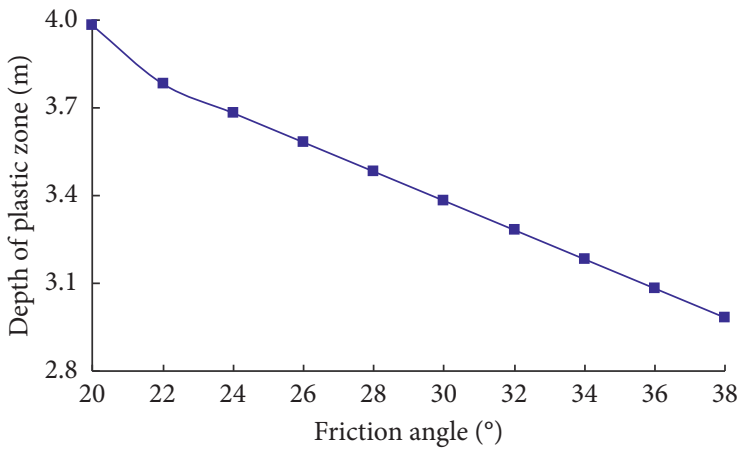

(b)

FIGURE 9: Relationship between the plastic zone of roadway and lithology. (a) $\Phi=30^{\circ}$. (b) $\mathrm{C}=1.2$.

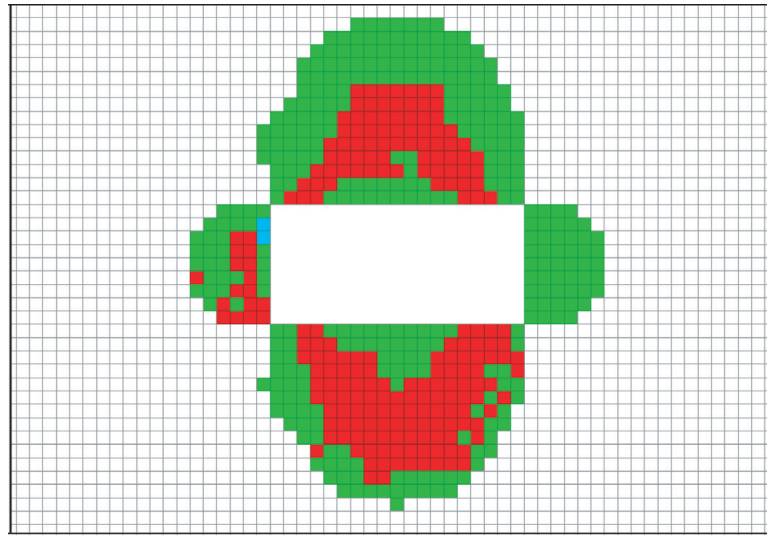

$\square$ None

Shear-n shear-p

Shear-n shear-p tension- $p$

Shear-p

Shear-p tension-p

Tension-p

(a)

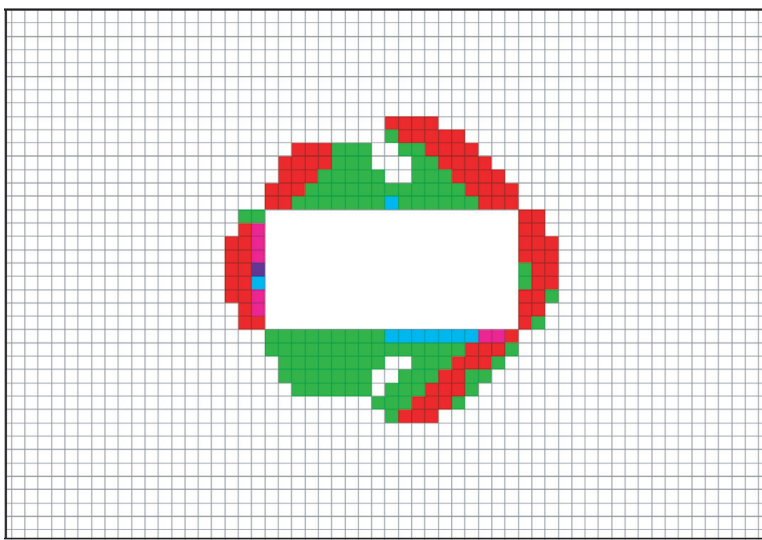

$\square$ None

Shear-n shear-p

Shear-n shear-p tension-p

Shear-p

Shear-p tension-p

Tension-p

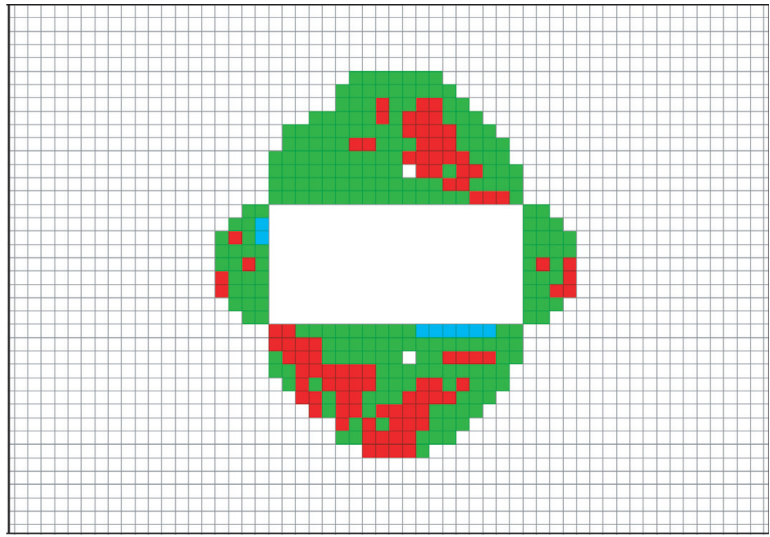

7 None

Shear-n shear-p

Shear-n shear-p tension- $p$

Shear-p

Shear-p tension-p

Tension-p

(b)

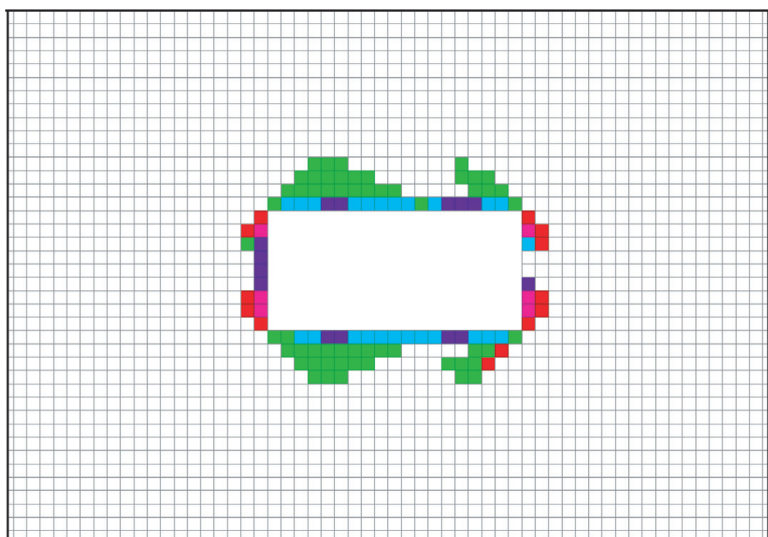

None

Shear-n shear-p

Shear-n shear-p tension-p

Shear-p

Shear-p tension-p

Tension-p

Figure 10: Continued. 


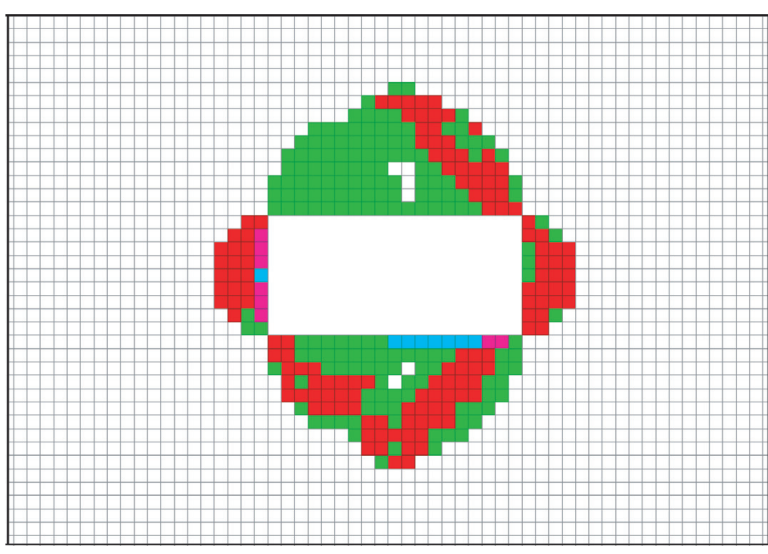

$\square$ None

Shear-n shear-p

Shear-n shear-p tension- $p$

Shear-p

Shear-p tension-p

Tension-p

(e)

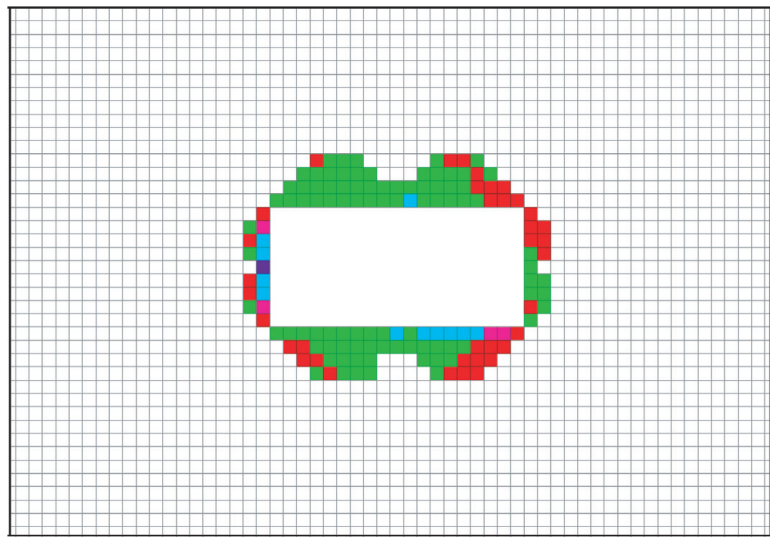

$\square$ None

Shear-n shear-p

Shear-n shear-p tension- $p$

Shear-p

Shear-p tension- $p$

Tension-p

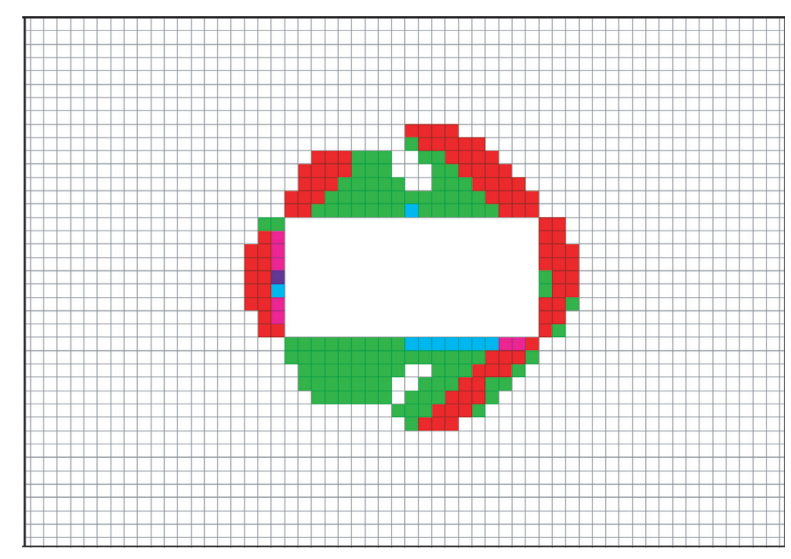

None

Shear-n shear-p

Shear- $n$ shear- $\mathrm{p}$ tension- $\mathrm{p}$

Shear-p

Shear-p tension- $p$

Tension-p

(f)

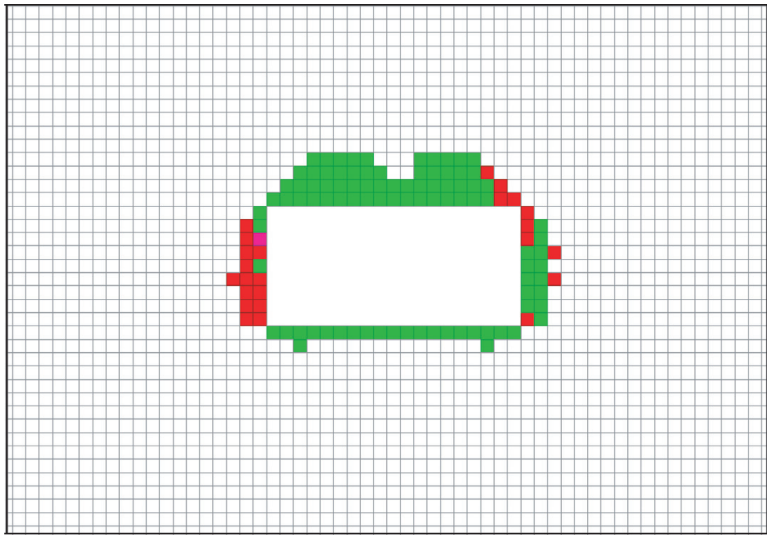

None

Shear-n shear-p

Shear- $n$ shear- $\mathrm{p}$ tension- $\mathrm{p}$

Shear-p

Shear-p tension- $p$

Tension-p

(h)

Figure 10: The distribution of plastic zone in different lithologies. (a) $\mathrm{C}=0.6, \Phi=25^{\circ}$, (b) $\mathrm{C}=0.9, \Phi=25^{\circ},(\mathrm{c}) \mathrm{C}=1.2, \Phi=25^{\circ}$, (d) $\mathrm{C}=1.5$, $\Phi=25^{\circ}$, (e) $\mathrm{C}=1.2, \Phi=20^{\circ}$, (f) $\mathrm{C}=1.2, \Phi=25^{\circ}$, (g) $\mathrm{C}=1.2, \Phi=30^{\circ}$, (h) $\mathrm{C}=1.2, \Phi=25^{\circ}$.

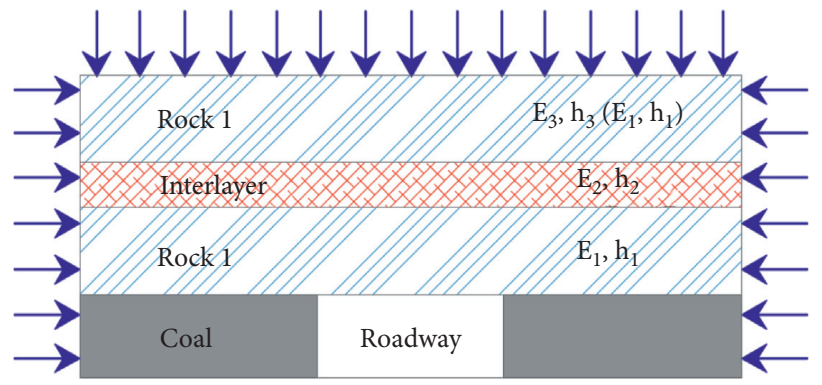

Figure 11: Simplified schematic diagram of roadway roof. 

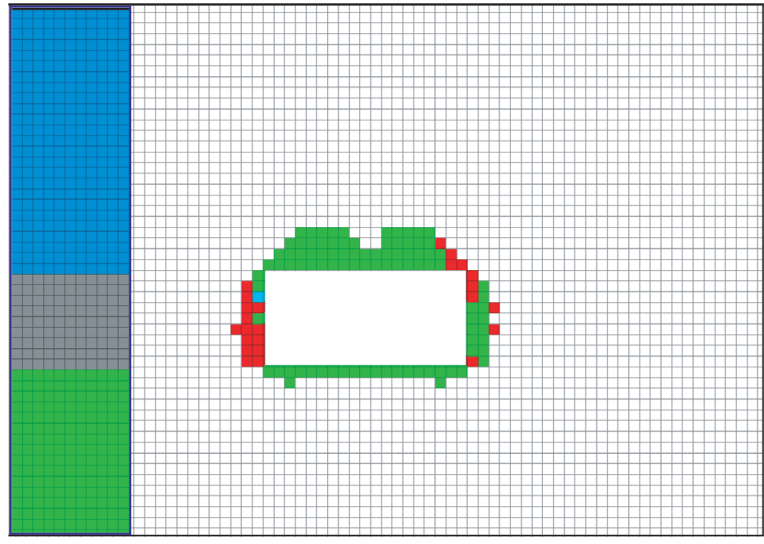

Zone

Plane: active on

Color by: group

Coal

Interlayer

Floor

Roof

Zone

Plane: active on

Color by: state

None

Shear-n shear-p

Shear-n shear- $p$ tension- $p$

Shear-p a)
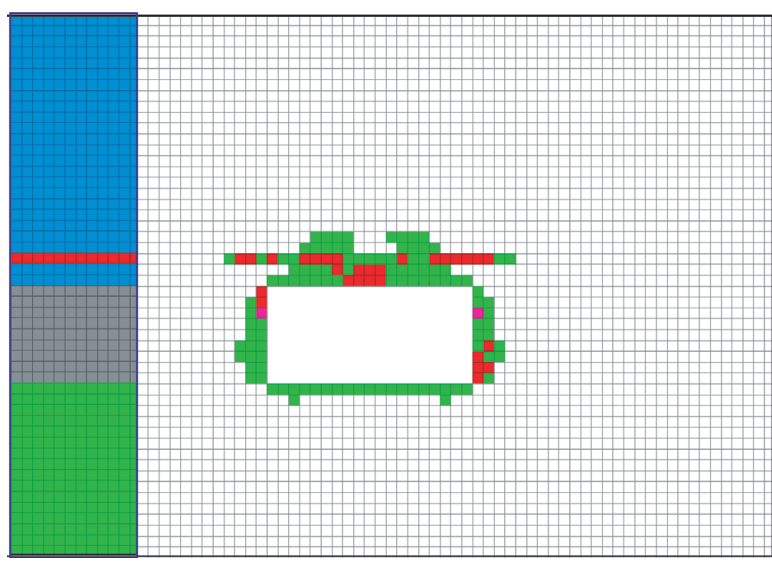

Zone

Plane: active on

Color by: group

Coal

Interlayer

Floor

Roof

Shear-n shear-p tension- $p$

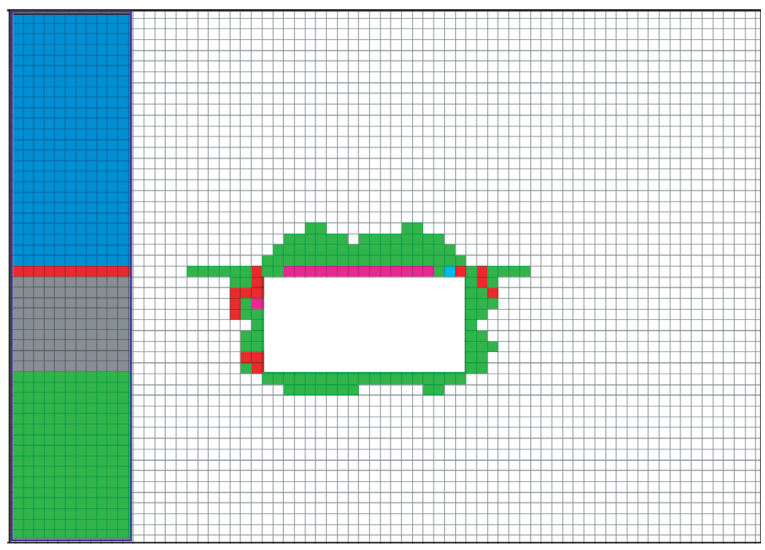

Zone

Plane: active on Plane: active on

Color by: group

Coal

Interlayer

Floor

Roof

Color by: state

None

Shear-n shear-p

Shear-n shear-p tension- $p$

Shear-p
Zone

Plane: active on

Color by: state

None

Shear-n shear-p

Shear-p

Shear-p tension- $p$
Shear-p tension- $\mathrm{p}$

(b)
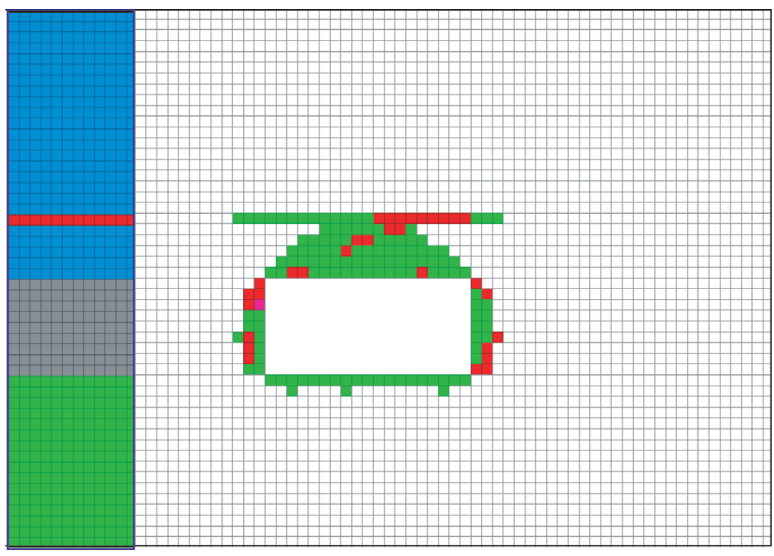

Zone

Zone

Plane: active on

Color by: group

Coal

Interlayer

Floor

Roof

(c)
Plane: active on

Color by: state

None

Shear-n shear-p

Shear-n shear-p tension- $\mathrm{p}$

Shear-p

Shear-p tension-p (d)

Figure 12: Continued. 


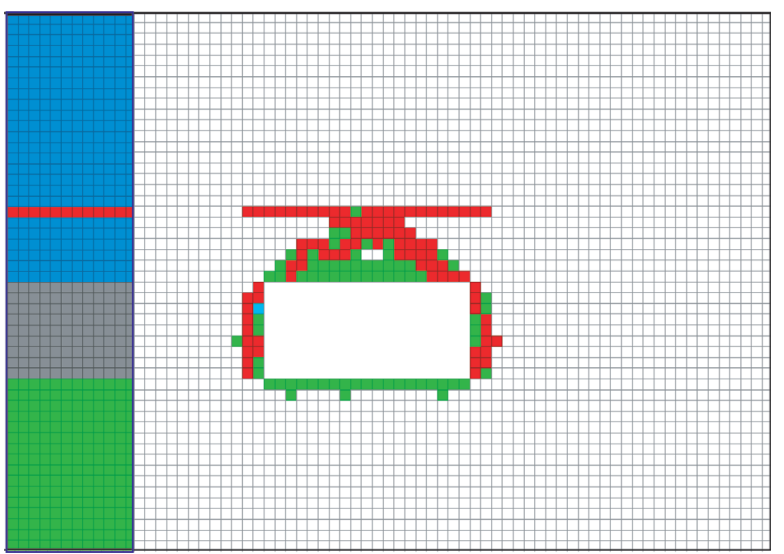

Zone

Plane: active on

Color by: group
Coal
Interlaye
Floor

Roof

\section{Zone}

Plane: active on

Color by: state

None

Shear-n shear-p

Shear- $n$ shear- $p$ tension- $p$
Shear-p tension-p

(e)
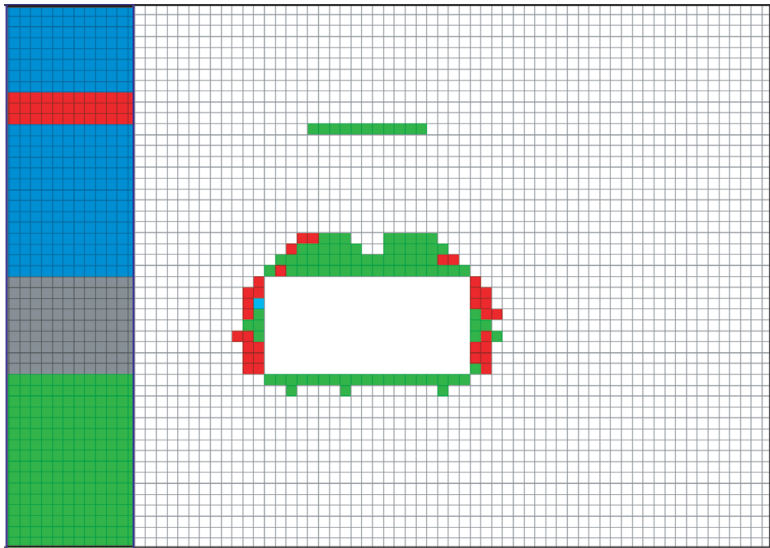

Zone

Plane: active on

Color by: group

Coal

Interlayer

Floor

Roof
Zone

Plane: active on

Color by: state

None

Shear-n shear-p

Shear-n shear-p tension- $p$

Shear-p

Shear- $p$ tension- $p$

(g)
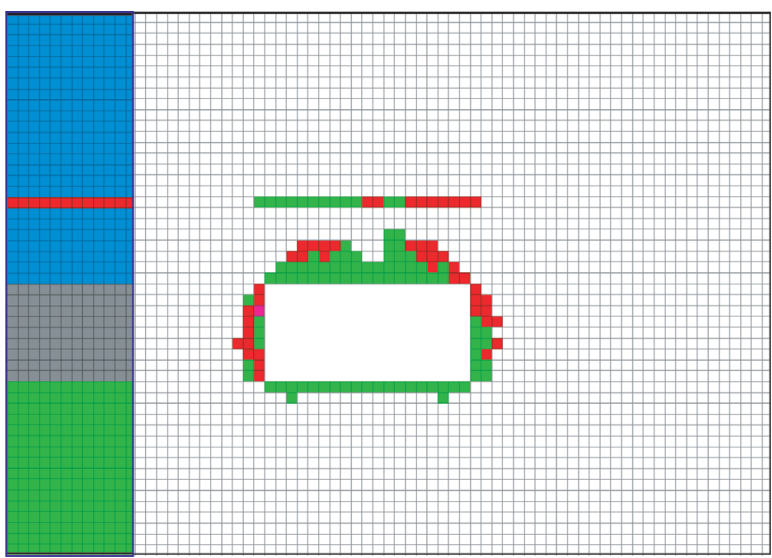

Zone

Zone

Plane: active on

Color by: group

Coal

Interlayer

Floor

Roof

Plane: active on

Color by: state

[ None

Shear-n shear-p

Shear-n shear- $p$ tension- $p$

Shear-p
Shear-p tension- $p$

(f)
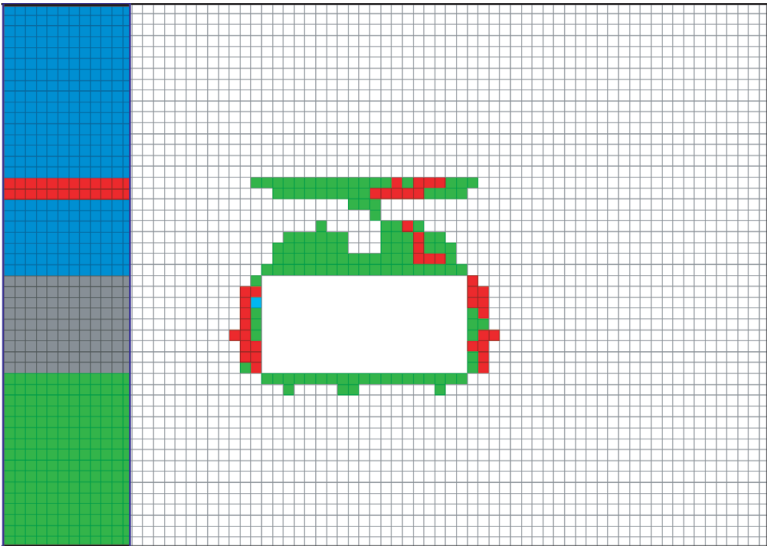

Zone

Plane: active on

Color by: group

Coal

Interlayer

Floor

Roof
Zone

Plane: active on

Color by: state

None

Shear-n shear-p

Shear-n shear-p tension-p

Shear-p

Shear-p tension- $p$

(h)

Figure 12: Continued. 

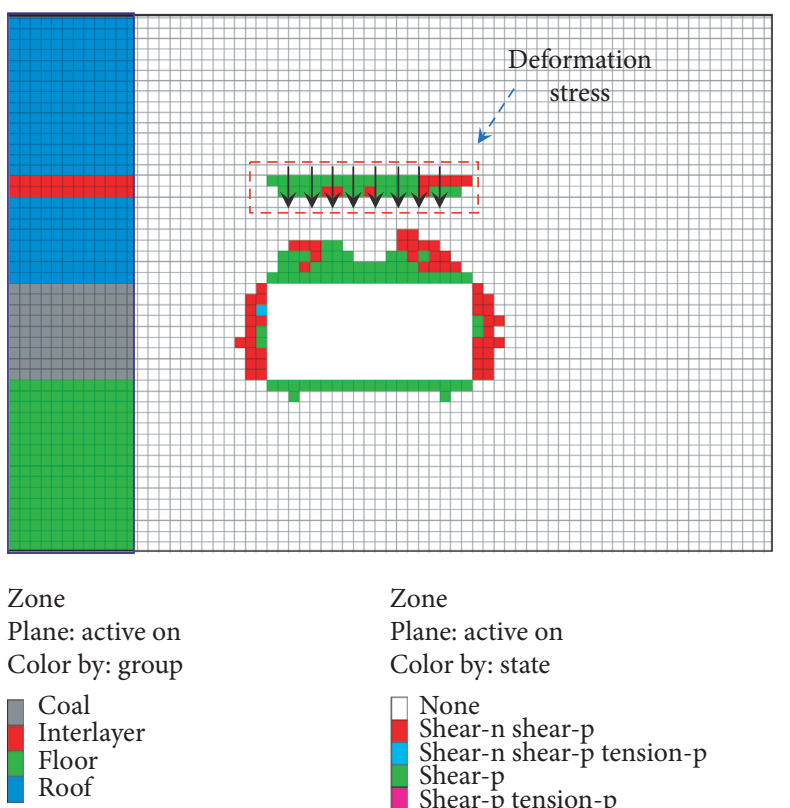

\begin{abstract}
Zone
Plane: active on

Color by: state

None

Shear-n shear-p

Shear-n shear- $\mathrm{p}$ tension- $\mathrm{p}$

Shear-p

Shear-p tension- $p$
\end{abstract}

(i)

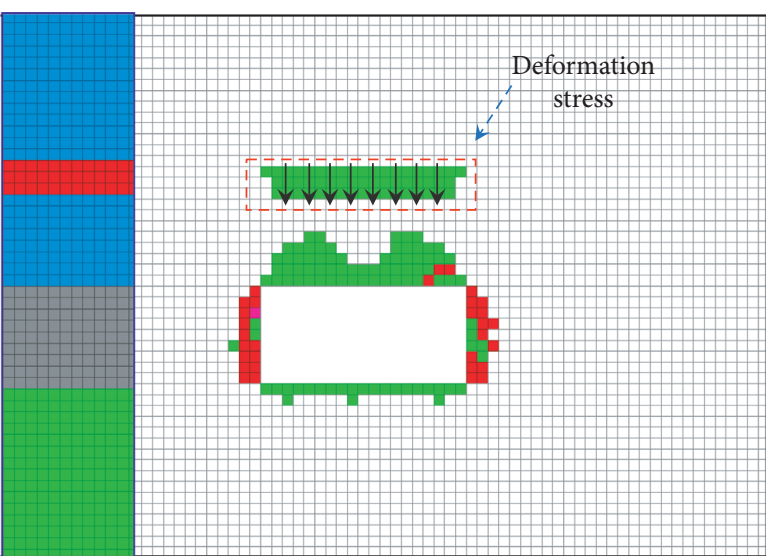

Zone

Plane: active on

Color by: group

Coal

Interlayer

Floor

Roof

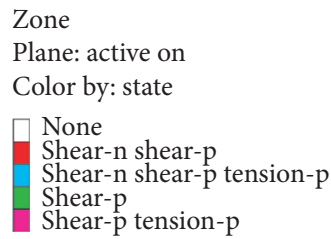

(j)

FiguRe 12: Influence of different interlayer states on the plastic zone. (a) No interlayers, (b) $0 \mathrm{~m}$ from the roof, (c) $0.8 \mathrm{~m}$ from the roof, (d) $2.0 \mathrm{~m}$ from the roof, (e) $2.4 \mathrm{~m}$ from the roof, (f) $2.8 \mathrm{~m}$ from the roof, (g) $5.6 \mathrm{~m}$ from the roof, (h) $2.8 \mathrm{~m}$ from the roof, (i) $3.2 \mathrm{~m}$ from the roof, and (j) $3.2 \mathrm{~m}$ from the roof.

Figure 12(e). When the soft interlayer with a thickness of $0.4 \mathrm{~m}$ was located above $2.8 \mathrm{~m}$ of the roof, there is a certain distance between the plastic zone of the soft interlayer and the plastic zone of the immediate roof. The plastic zone of the roof below the soft interlayer was consistent with Figures 12(f) 12(g). The plastic failure of the soft interlayer in the roof occurs because the soft interlayer reaches its failure limit under the condition of the given stress environment $[24,26]$. However, the failure of the soft interlayer in the roof has a limit depth, and the limit failure depth of the soft interlayer in this open-off cut was $5.6 \mathrm{~m}$, as shown in Figure $12(\mathrm{~g})$. The influence of the soft interlayer thickness on the roof stability was also obvious $[27,38]$. When the soft interlayer was increased from $0.4 \mathrm{~m}$ to $0.8 \mathrm{~m}$, the effect of the soft interlayer on the expansion of the roof plastic zone was also increased by $0.8 \mathrm{~m}$, as shown in Figures 12(f)-12(h). When the soft interlayer was located within $2.8 \mathrm{~m}$ above the roof, the extended plastic zone of the soft interlayer will be connected with the plastic zone of the immediate roof, which will constitute the potential roof falling zone of the open-off cut roof, as shown in Figure 12(h). The thickness of the soft interlayer cannot affect the expansion of the immediate roof plastic zone indefinitely. When the soft interlayer was $3.2 \mathrm{~m}$ above the roof, the increase of soft interlayer thickness would not lead to the connection between the soft interlayer plastic zone and the immediate roof plastic zone. At the same time, the expansion pressure in the plastic zone of the weak interlayer will promote the roof instability, as shown in Figures 12(i) and 12(j).

To sum up, the dramatic influence of $0.4 \mathrm{~m}$ and $0.8 \mathrm{~m}$ soft interlayers on roof instability was $2.4 \mathrm{~m}$ and $2.8 \mathrm{~m}$, respectively. The thicker the soft interlayer, the greater the influence on the failure depth of the roof, but the critical depth was $5.6 \mathrm{~m}$. Besides, the bearing capacity of the soft interlayer was weakened after plastic failure. The deformation pressure released by the interlayer plastic zone acted on the immediate roof and posed a threat to the roof stability, as shown in Figure 13.

4.3. Roof Failure Mechanism of Open-OffCut. The numerical simulation of the open-off cut was carried out based on roof structure detection and relevant geological data. Combined with field monitoring, numerical simulation, and theoretical analysis, the failure mechanism of the open-off cut roof can be obtained, as described below.

(1) The lithology of the open-off cut roof is weak. The surrounding rock strength is low and the bearing capacity is poor, which is greatly affected by excavation disturbance $[10,38]$. Plastic failure occurs when the regional stress field exceeds the rock strength after open-off cut excavation. The weakly consolidated rock mass has significant characteristics of postpeak strain softening and volume dilatancy deformation, which further intensifies the surrounding rock failure [39].

(2) The open-off cut roof contains a soft interlayer. The soft interlayer layer will first breakdown and produce a plastic zone after the open-off cut excavation when the soft interlayer is located in the shallow part of the roof, and then, it will develop to the two sides, which is easy to cause layered roof falling [24]. When the 


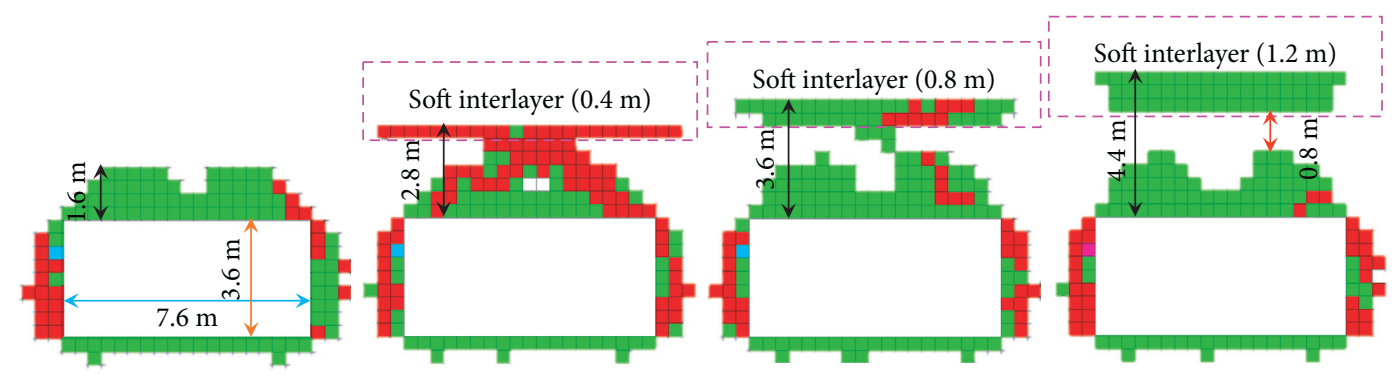

FIGURE 13: Distribution of plastic zone in open-off cut surrounding rock.
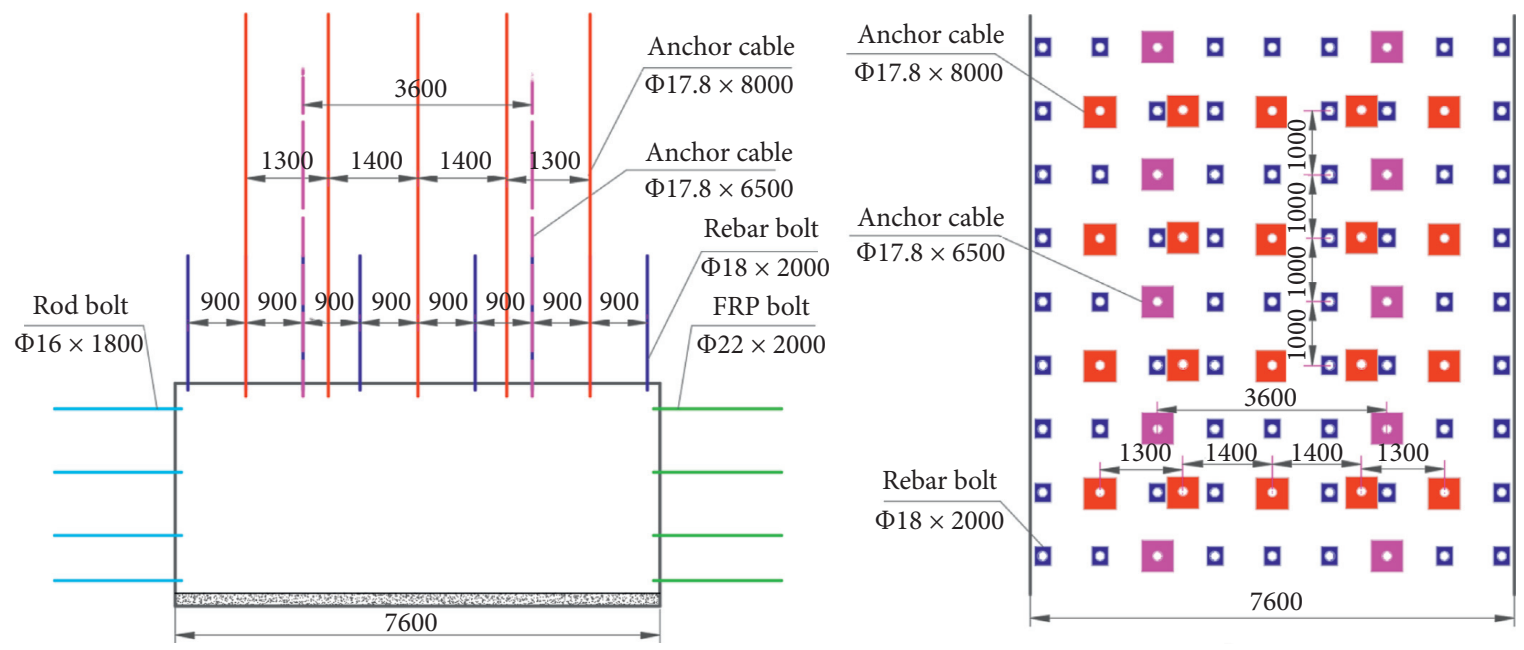

FIGURE 14: Design support scheme of 31207 open-off cut.

soft interlayer is deep in the roof and the thickness is large, the interlayer above the intact roof will still produce plastic failure and release the expansion pressure after open-off cut excavation. The expansion pressure acts on the immediate roof in the form of load, thus forming a potential roof falling zone and threatening roof safety [26]. In addition, the bolt's supporting function will be seriously affected when its anchorage end is located in the soft interlayer, which results in immediate roof instability.

(3) The open-off cut section is larger. The section of the open-off cut is relatively large due to its specific functional properties, and with the increase of the chamber section, the stress concentration degree of surrounding rock, the fracture area, and the plastic zone are increased, and the phenomenon of roof falling is easy to appear [40].

(4) Existing support is not reasonable. The supporting parameter adopted now is uniform, and it has not been changed or optimized according to different geological conditions [41, 42]. For example, the length of the roof anchor cable is always $8 \mathrm{~m}$, but the cable anchoring effect is inconsistent in different rock strata. The immediate roof plastic zone is larger than the bolt length, so that the bolt may move with the surrounding rock in the plastic zone, but the spacing of anchor cables is too large.

\section{Implementation Schemes}

5.1. Support Function Analysis of Bolt and Anchor Cable. When adopting bolts to support the soft rock roadway, the roof damage range often exceeds the bolt support range. At this time, the function of the bolt is to improve the residual strength of the rock stratum to improve the bearing capacity and stability of the roof. However, without a certain density of anchor cable to provide timely and effective support, the bolt and the rock within the plastic zone will move together and collapse. Therefore, the shallow bolt support must be combined with a certain density of anchor cable support $[32,43,44]$. Because of the uncertainty of the interlayer position above the roof, there is a hidden danger of using a single length anchor cable. Therefore, the use of long and short anchor cables is to control the central and deep surrounding rocks, and the use of bolts is to control the shallow surrounding rocks. The shallow-medium-deep support system can guarantee the roof stability.

5.2. Supporting Scheme. The open-off cut roof was supported by the method of "left-rotation non-longitudinal reinforcement rebar bolt + anchor cable $+W$ steel belt + metal welding net." Rebar bolt with a diameter of $18 \mathrm{~mm}$ and length of $2500 \mathrm{~mm}$ is selected, and a " $6-7-6$ " " layout is adopted with a row spacing of $1000 \mathrm{~mm}$. The anchor cable with a diameter of $17.8 \mathrm{~mm}$ was selected, and the length was 


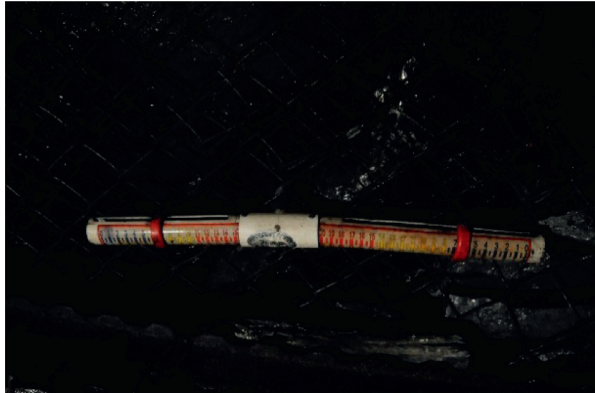

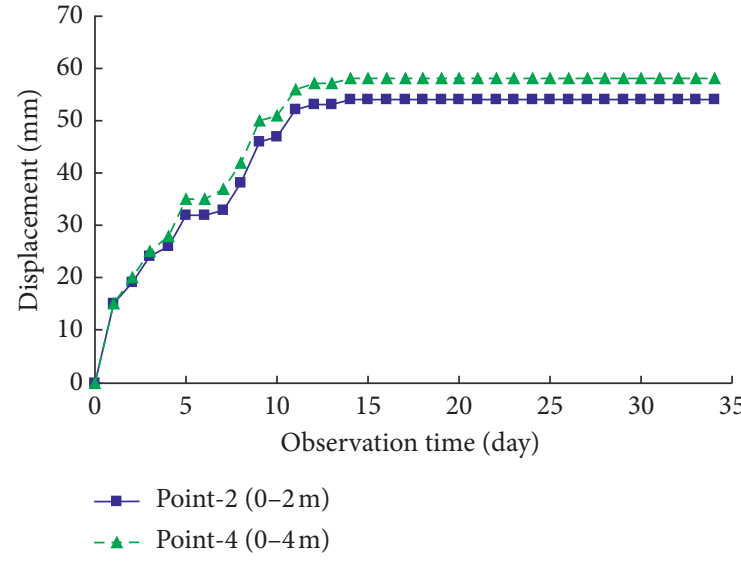

(b)

Figure 15: Roof deformation observation. (a) Field monitoring instrument. (b) Roof deformation trend.

divided into two categories: $8000 \mathrm{~mm}$ and $6000 \mathrm{~mm}$. The layout was " $5-2-5$ "” and the row spacing was $1000 \mathrm{~mm}$. The support parameters of the roadway ribs remained unchanged. Figure 14 shows the supporting diagram of panel 31207 open-off cut.

5.3. Field Application and Monitoring. Bolt and anchor cable support scheme as shown in Figure 14 was applied to 31207 open-off cut. During the excavation of the 31207 open-off cut, six observation stations of the basis point separation monitor were uniformly arranged. The installation of the station started $5 \mathrm{~m}$ behind the driving working face, and the observation stations shall be read before the daily morning shift. The following patterns were found by continuous readings of the installed measuring points. The roof sags up to $56 \mathrm{~mm}$, and deformation was within $2 \mathrm{~m}$. Deformation tended to be stable after 10 days of roadway excavation. The maximum deformation law measured is shown in Figure 15.

\section{Conclusion}

Through the systematic study of large section open-off cut in soft stratum, we mainly get the conclusion.

(1) The failure characteristics, rock structure, and strength of 31206 open-off cut roofs were obtained by field monitoring. The maximum amount of roof subsidence in the open-off cut is $160 \mathrm{~mm}$. The damage of surrounding rock is mainly concentrated within $2.5 \mathrm{~m}$ above the roof. The immediate roof contains a mudstone soft interlayer with a thickness of $0.4-0.6 \mathrm{~m}$. The anchoring force of the roof anchor cable is related to the rock strength at the anchorage end.

(2) The dimensions of the plastic zone are negatively correlated with cohesion and internal friction angle. Soft interlayer above roof promotes the expansion of the plastic zone. Different positions of the soft interlayer have different effects on roof instability, and the thicker the soft interlayer is, the greater the hidden danger is. Besides, the ultimate influence height of the soft interlayer on the roof is $5.6 \mathrm{~m}$, and the interlayer outside this height range does not influence the roof.

(3) The damage mechanism of the open-off cut roof is obtained, and specific control techniques are proposed. Roof failure is the result of the weak surrounding rock, the soft interlayer above the roof, the large section, and the unreasonable support. The shallow-middle-deep support system of bolt and anchor cable is proposed, and the effect of surrounding rock control is good after application.

\section{Data Availability}

The data used to support the findings of this study are available from the corresponding author upon request.

\section{Conflicts of Interest}

The authors declare that they have no conflicts of interest.

\section{Authors' Contributions}

C. Li and J. Li conceptualized the study; C. Li and Y. E. Li developed methodology; X. Y. Lian and Q. Xue investigated the study; C. Li and J. C. Feng wrote the article.

\section{Acknowledgments}

This work was partially supported by the National Natural Science Foundation of China (51804118).

\section{References}

[1] C. Zhang, S. H. Tu, and Y. X. Zhao, "Compaction characteristics of the caving zone in a longwall goaf: a review," Environmental Earth Sciences, vol. 79, p. 27, 2019.

[2] S. Xie, Q. Zhang, D. Chen et al., "Research of roof anchorage rock beam bearing structure model of extra-large width openoff cut and its engineering application in a coal mine, China," 
Advances in Civil Engineering, vol. 2020, Article ID 3093294, 19 pages, 2020.

[3] Y. Hu, Y. Liu, and L. Shi, "Research on supporting technology for surrounding rock of inclined large-span open-off cut roadway," Geotechnical and Geological Engineering, vol. 38, no. 2, pp. 1873-1884, 2020.

[4] W. T. Li, Q. Wang, S. C. Li, and D. C. Wang, "Deformation and failure mechanism analysis and control of deep roadway with intercalated coal seam in roof," Journal of China Coal Society, vol. 39, no. 1, pp. 47-56, 2014.

[5] J. K. Li and H. Wang, "Ground support of interbedded rock roof in a deep roadway with fully-anchored cables," Journal of Mining and Strata Control Engineering, vol. 2, no. 3, pp. 14-22, 2020.

[6] C. Zhang, F. T. Wang, and Q. S. Bai, "Underground space utilization of coalmines in China: a review of underground water reservoir construction," Tunnelling and Underground Space Technology, vol. 107, Article ID 103657, 2021.

[7] F. Du, K. Wang, X. Zhang, C. Xin, L. Shu, and G. Wang, "Experimental study of coal-gas outburst: insights from coalrock structure, gas pressure and adsorptivity," Natural Resources Research, vol. 29, no. 4, pp. 2481-2493, 2020.

[8] H. S. Jia, N. J. Ma, X. D. Zhao, and S. K. Zhang, "Research on the law of instability and caving for large-span cut-hole roof with thin bedrock in depth," Journal of Mining and Safety Engineering, vol. 31, no. 5, pp. 702-708, 2014.

[9] S. Du, D. Li, and J. Sun, "Stability control and support optimization for a soft-rock roadway in dipping layered strata," Geotechnical and Geological Engineering, vol. 37, no. 3, pp. 2189-2205, 2019.

[10] L. Shi, H. Zhang, and P. Wang, "Research on key technologies of floor heave control in soft rock roadway," Advances in Civil Engineering, vol. 2020, Article ID 8857873, 13 pages, 2020.

[11] B. Shen, "Coal mine roadway stability in soft rock: a case study," Rock Mechanics and Rock Engineering, vol. 47, no. 6, pp. 2225-2238, 2014.

[12] H. Y. Wang, B. Tan, Z. Z. Shao, Y. Guo, Z. L. Zhang, and C. F. $\mathrm{Xu}$, "Influence of different content of FeS2 on spontaneous combustion characteristics of coal," Fuel, vol. 228, Article ID 119582, 2021.

[13] G. Li, F. S. Ma, J. Guo, H. J. Zhao, and G. Liu, "Study on deformation failure mechanism and support technology of deep soft rock roadway," Engineering Geology, vol. 264, pp. 1-15, 2020.

[14] H. Wang, P.-q. Zheng, W.-j. Zhao, and H.-m. Tian, "Application of a combined supporting technology with u-shaped steel support and anchor-grouting to surrounding soft rock reinforcement in roadway," Journal of Central South University, vol. 25, no. 5, pp. 1240-1250, 2018.

[15] C. Li, X. F. Guo, X. Y. Lian, and N. J. Ma, "Failure analysis of a pre-excavation double equipment withdrawal channel and its control techniques," Energies, vol. 13, no. 23, pp. 1-17, 2020.

[16] X. J. Liu, S. L. Song, D. Y. Fan, and W. C. Fan, "Experimental study on deformation and failure evolution of surrounding rock for deep super-large section chamber group," Journal of Mining and Safety Engineering, vol. 37, no. 1, pp. 40-49, 2020.

[17] F. Du and K. Wang, "Unstable failure of gas-bearing coal-rock combination bodies: insights from physical experiments and numerical simulations," Process Safety and Environmental Protection, vol. 129, pp. 264-279, 2019.

[18] Y. Tai, H. C. Xia, H. J. Liu, Z. Y. Ma, and Y. Q. Zhang, "Control for the large section roadway under small abandoned mines in the same coal seam by secondary support," Energy Science \& Engineering, vol. 8, no. 11, pp. 1-14, 2020.
[19] X. Gao, Y. Luan, C. Hu et al., "Study on bearing mechanism and coupling mechanism of steel arch-concrete composite structure of initial support system of large section tunnel," Geotechnical and Geological Engineering, vol. 37, no. 6, pp. 4877-4887, 2019.

[20] R. Pan, Q. Wang, B. Jiang, and S. C. Li, "Model test on failure and control mechanism of surrounding rocks in tunnels with super large sections," Arabian Journal of Geosciences, vol. 12, no. 22, pp. 687-704, 2019.

[21] H. Yan, F. L. He, and S. G. Wang, "Safety control and evaluation of roadway with super-large cross-section and softweak thick coal roof," Chinese Journal of Rock Mechanics and Engineering, vol. 33, no. 5, pp. 1014-1023, 2014.

[22] Y. Y. Li, K. Xie, Y. M. Sun, S. H. Li, and X. H. An, "Stress and deformation analysis and reinforcement time selection of composite foundations in shallow loess tunnels," Chinese Journal of Rock Mechanics and Engineering, vol. 38, no. 11, pp. 2332-2343, 2019.

[23] P. Liang and Y. T. Gao, "Numerical investigation on cracking behavior of granite with intersecting two-flaws: a flat-joint modeling method," Latin American Journal of Solids and Structures, vol. 17, no. 4, pp. 1-14, 2020.

[24] M. K. Jia, "Research on roof falling mechanism of deteriorative strata combination supported by bolts," Rock and Soil Mechanics, vol. 28, no. 7, pp. 1333-1337, 2007.

[25] H. Y. Wang, X. Y. Fang, Y. C. Li, Z. Y. Zheng, and J. T. Shen, "Research and application of the underground fire detection technology based on multi-dimensional data fusion," Tunnelling and Underground Space Technology, vol. 109, Article ID 103753, 2021.

[26] N. J. Ma, P. Zhan, G. He, and Q. Xiang, "On soft inter layer affecting roadway stabilization in roof," Mineral Engineering Research, vol. 24, no. 4, pp. 1-4, 2009.

[27] S. W. Liu, R. G. Xu, H. Zhang, and X. W. Zheng, "Instability mechanism and classification of lamellate roof with intercalated weak seam in roadway," Journal of Henan Polytechnic University (Natural Science), vol. 29, no. 1, pp. 23-27, 2010.

[28] S. J. Chen, D. W. Yin, N. Jiang, F. Wang, and Z. H. Zhao, "Mechanical properties of oil shale-coal composite samples," International Journal of Rock Mechanics and Mining Sciences, vol. 123, Article ID 104120, 2019.

[29] H. P. Kang, G. Xu, B. M. Wang et al., "Forty years development and prospects of underground coal mining and strata control technologies in China," Journal of Mining and Strata Control Engineering, vol. 1, no. 1, 2019.

[30] K. Wang and F. Du, "Coal-gas compound dynamic disasters in China: a review," Process Safety and Environmental Protection, vol. 133, pp. 1-17, 2020.

[31] M. G. Qian, P. W. Shi, and J. L. Xu, Mining Pressure and Strata Control, China University of Mining and Technology Press, Beijing, China, 2010.

[32] M. F. Cai, "Key theories and technologies for surrounding rock stability and ground control in deep mining," Journal of Mining and Strata Control Engineering, vol. 2, no. 3, pp. 5-13, 2020.

[33] F. Q. Gao, "Use of numerical modeling for analyzing rock mechanic problems in underground coal mine practices," Journal of Mining and Strata Control Engineering, vol. 1, no. 1, pp. 21-28, 2019.

[34] X. Y. Yu, Z. S. Wang, Y. Yang, and X. W. Mao, "Movement rule of overburden in fully mechanized caving mining with thick depth and high mining height based on 3DEC," Journal of Mining and Strata Control Engineering, vol. 3, no. 1, pp. 28-38, 2021. 
[35] H. Y. Wang, X. Y. Fang, F. Du et al., "Three-dimensional distribution and oxidation degree analysis of coal gangue dump fire area: a case study," Science of the Total Environment, vol. 772, Article ID 145606, 2021.

[36] N. J. Ma, J. Li, and Z. Q. Zhao, "Distribution of the deviatoric stress field and plastic zone in circular roadway surrounding rock," Journal of China University of Mining \& Technology, vol. 44, no. 2, pp. 209-213, 2015.

[37] X. Guo, Z. Zhao, X. Gao, X. Wu, and N. Ma, "Analytical solutions for characteristic radii of circular roadway surrounding rock plastic zone and their application," International Journal of Mining Science and Technology, vol. 29, no. 2, pp. 263-272, 2019.

[38] Q. B. Meng, L. J. Han, W. G. Qiao, and D. G. Lin, "Deformation failure characteristics and mechanism analysis of muddy weakly cemented soft rock roadway," Journal of Mining and Safety Engineering, vol. 33, no. 6, pp. 1014-1022, 2016.

[39] Q. B. Meng, L. J. Han, W. G. Qiao, and H. Pu, "Elastic-plastic analysis of the weakly cemented surrounding rock considering characteristics of strain softening and expansion," Journal of China University of Mining \& Technology, vol. 47, no. 4, pp. 760-767, 2018.

[40] T. Q. Xiao, H. M. Li, J. L. Yang, and S. Y. Jiang, "Deformation and failure mechanism of surrounding rock in chamber with super large section and its control," Journal of China Coal Society, vol. 39, no. 4, pp. 631-636, 2015.

[41] Y. Sun, G. Li, J. Zhang, and D. Qian, "Experimental and numerical investigation on a novel support system for controlling roadway deformation in underground coal mines," Energy Science \& Engineering, vol. 8, no. 2, pp. 490-500, 2020.

[42] J. J. Shi, J. C. Feng, P. Rui, and Q. J. Zhu, "Optimization analysis of over-sized section open-off cut failure and support," Geotechnical and Geological Engineering, vol. 38, no. S1, pp. 3283-3290, 2020.

[43] C. Li, Z. Wu, W. L. Zhang, Y. H. Sun, C. Zhu, and X. H. Zhang, "A case study on asymmetric deformation mechanism of the reserved roadway under mining influences and its control techniques," Geomechanics and Engineering, vol. 22, no. 5, pp. 449-460, 2020.

[44] H. P. Kang, "Spatial scale analysis on coalmining and strata control technologies," Journal of Mining and Strata Control Engineering, vol. 2, no. 2, pp. 5-30, 2020. 